\title{
DECREASING DISPLACEMENTS OF PRESTRESSED SUSPENSION BRIDGE
}

\author{
Vadims Goremikins ${ }^{1}$, Karlis Rocens ${ }^{2}$, Dmitrijs Serdjuks ${ }^{3}$ \\ Department of Structural Engineering, Riga Technical University, Azenes Street 16/20, LV 1048 Riga, Latvia \\ E-mail:' goremikin@inbox.lv (corresponding author)
}

Received 01 Dec. 2011; accepted 20 Feb. 2012

\begin{abstract}
A suspension bridge is the most suitable type for a long-span bridge due to rational use of structural materials. Increased deformability, which is conditioned by the appearance of the elastic and kinematic displacements, is the major disadvantage of suspension bridges.

The problem of increased kinematic displacements under the action of symmetrical and non-symmetrical load can be solved by the prestressing. A prestressed suspension bridge with span of $200 \mathrm{~m}$ was considered as an object of investigations. The cable truss with the cross web was considered as the main load carrying structure of prestressed suspension bridges and was compared with the single cable. The considered prestressed suspension bridge was investigated by the FEM program ANSYS 12 and by the small scale physical model.

Rational, from the point of view of minimal vertical kinematic displacements, main load-carrying structure of prestressed suspension bridge was developed. The obtained results shows, that usage of cable truss with the cross web as the main load carrying structures of prestressed suspension bridge in comparison with the single cable, reduces vertical displacements upwards by $63.1 \%$, downwards by $1.8 \%$ and total displacements by $29.6 \%$ under the action of worth situated load.
\end{abstract}

Keywords: cable truss, kinematic vertical displacements, non-symmetrical load, genetic algorithm.

\section{Introduction}

Suspension bridges are structures where the deck is continuously supported by stretched catenary cable (Chen, Lui 2005). Suspension bridges are the most important and attractive structures possessing a number of technical, economical and aesthetic advantages (Grigorjeva et al. 2010)

At the present moment, a suspension bridge is the most suitable type of structure for very long-span bridges. Suspension bridges represent 20 or more of all the longest span bridges in the world. The bridge with the longest centre span of $1991 \mathrm{~m}$ is Akashi Kaikyo Bridge (Chen, Duan 2000). So long spans can be achieved because main load carrying cables are subjected to tension and distribution of normal stresses are close to uniform (Jouzapaitis et al. 2010).

Increased deformability is one of the basic disadvantages of suspension bridges (Hambly 1998; Walther et al. 1999). Increased deformability is conditioned by appearance of elastic and non-straining (kinematic) displacements. The elastic displacements are caused by large tensile inner forces. Kinematic displacements are caused by initial parabolic shape change, resulting from nonsymmetrical or local loads (Fig. 1) (Grigorjeva et al. 2008). Serviceability limit state is dominating for suspension cable structures.

The problem of increased kinematic displacements can be solved by increasing the relation of dead weight to imposed load, which is achieved by adding of cantledge
(Fig. 2) (Starsky 2005). But this method causes the increase of material consumption.

Usage of prestressed cable truss is another method of fixing the problem of increased kinematic displacements under the action of unsymmetrical load (Fig. 3) (Serdjuks, Rocens 2004; Mikhailov 2002; Tibert 1999; Kirsanov 1973). This method allows the development of bridges with reduced requirements for girder stiffness, but overall bridge rigidity will be ensured by prestressing of stabilization cable (Kirsanov 1973). The deck can be made of light composite materials. The kinematic displacements can be decreased by using of cable truss with a cross web instead of single cable as a top chord structure (Fig. 4) (Goremikins et al. 2011).

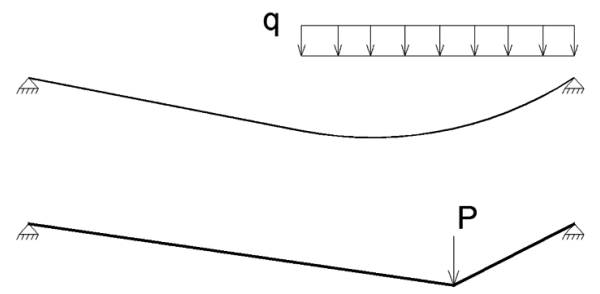

Fig. 1. Initial shape change under the action of non-symmetrical load

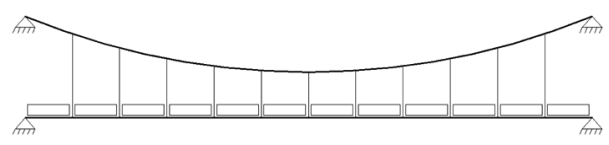

Fig. 2. Suspension bridge stabilization by the adding of cantledge 


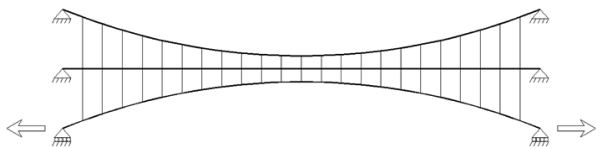

Fig. 3. Suspension bridge stabilization by the prestressing

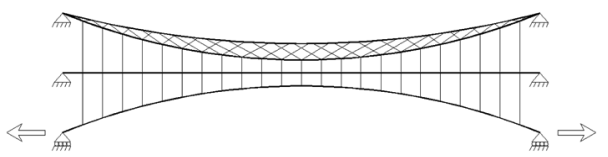

Fig. 4. Suspension bridge stabilization by the using of prestressed stabilization cable and cable truss

The possibility of prestressed suspension bridges development is evaluated. The optimization of cable truss with cross web is presented in this research. Prestressed suspension bridge with cable truss is compared with simply prestressed suspension bridge. Obtained results are verified on the small scale physical models of prestressed suspension bridges. Only main span of the bridge is analyzed.

\section{Structure of the bridge}

Two prestressed suspension bridges were chosen as objects of investigation. First one is a prestressed suspension bridge with a single main load-carrying cable (Fig. 5); second one is a prestressed suspension bridge with a cable truss (Fig. 6).

Main span of bridges $l$ is equal to $200 \mathrm{~m}$. The distances from the top of pylon and from the connection of stabilization cable up to the deck are equal to $21 \mathrm{~m}$ and $11 \mathrm{~m}$, respectively. The bridges have two lines in each direction, two pedestrian lines and their total width

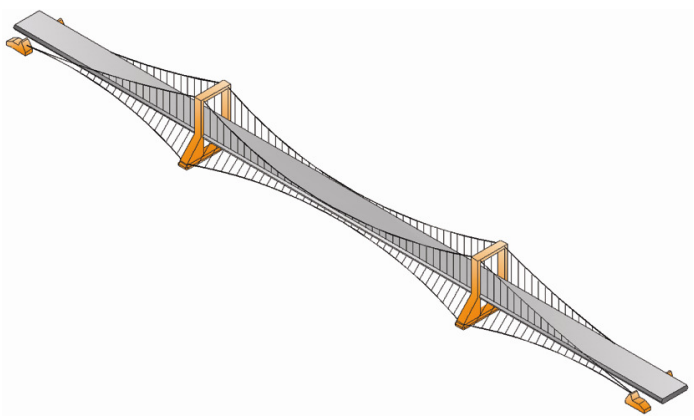

Fig. 5. Prestressed suspension bridge with single main load carrying cable

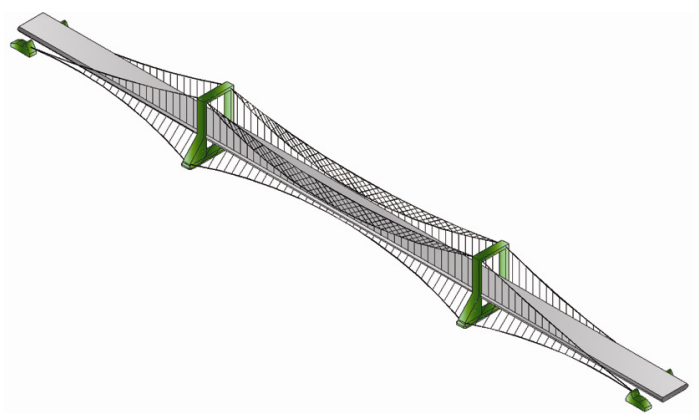

Fig. 6. Prestressed suspension bridge with cable truss load carrying structure is equal to $18.2 \mathrm{~m}$ (Fig. 7). The single cable and cable truss are the main load-carrying structures of the first and second bridges, respectively. The chambers of single cable and cable truss bottom chord $f_{b}$ are equal to $20 \mathrm{~m}$. The bridges are prestressed in horizontal and vertical planes by stabilization cables. Stabilization cable camber is equal to $10 \mathrm{~m}$. The deck is connected with the main load-carrying cables by suspensions with step $a$ equal to $5 \mathrm{~m}$ (Fig. 8). The cable string is placed between suspensions to minimize horizontal prestressing force effects acting in the deck. Prestressed horizontal cables were placed along the deck to minimize effects of horizontal braking force (Fig. 9). Bridge deck is made of pultrusion composite trussed beams, pultrusion composite beams with step $1 \mathrm{~m}$ and a pultrusion composite plank with height $40 \mathrm{~mm}$ that is covered with an asphalt layer (Fig. 7) (Goremikins et al. 2010a, b, c, d; Fiberline Composites 2002). It is assumed that cables are covered with high-density polyethylene and are heated with electricity to reduce the influence of temperature effects (Xiang et al. 2009). Possible prestressing loosing is reduced by active tendons (Achkire, Preumont 1996).

It is possible to reduce requirements for girder stiffness by bridge prestressing. This aspect allows the use of composite pultrusion materials in the deck structure and makes possible to develop construction of bridges with large span and reduced dead weight in comparison with steel or concrete bridges (Bakhtin et al. 1999).

Design scheme of the investigation object is shown in Figs 8 and 9. The structural material is prestressed steel rope (Eurocode 3 2007; Feyrer 2007). The dead load $g$ that is applied to the structure is equal to $51.1 \mathrm{kN} / \mathrm{m}$. The bridge is loaded by the load-model LM:1 (Fig. 10) (Eurocode 1 2004). Imposed load $q$, which is equal to

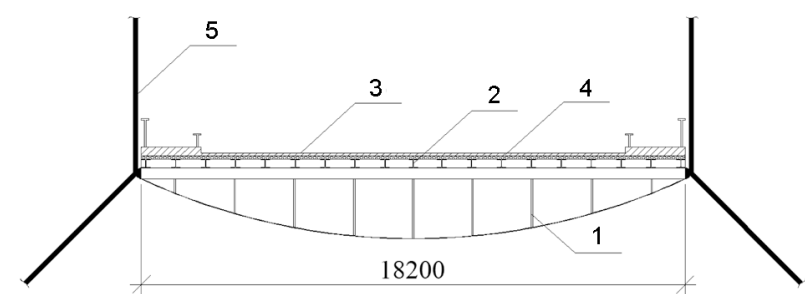

Fig. 7. The bridge deck structure: 1 - composite trussed beam; 2 - composite I type beams; 3 - composite plank; 4 - cover of the bridge; 5 - suspensions

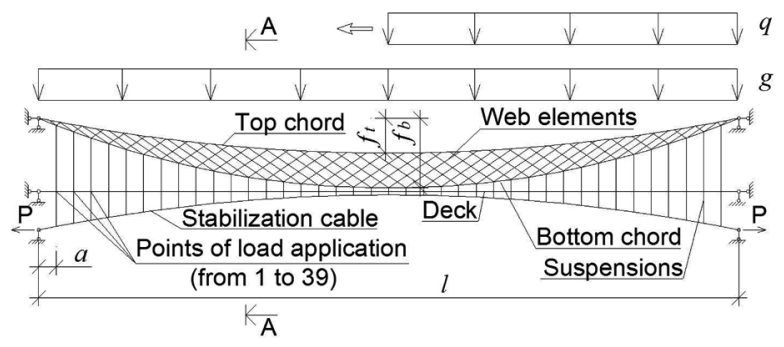

Fig. 8. Design scheme of suspension bridge: $q$-imposed load; $g$-dead load; $P$ - prestressing; $f_{\mathrm{b}}$ - bottom chord camber; $f_{t}-$ top chord camber; $l$ - main span; $b$-width; $a$ - suspension step 


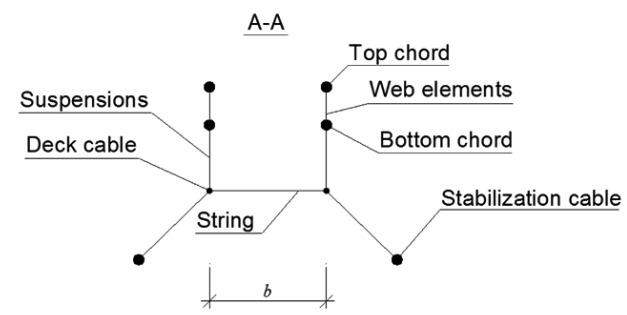

Fig. 9. Cross section of prestressed suspension bridge

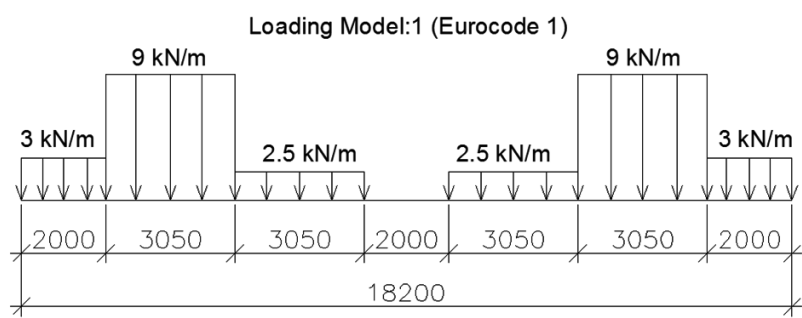

Fig. 10. Imposed load on traffic lines and pedestrian lines according to EC

$82.2 \mathrm{kN} / \mathrm{m}$, can be applied to any place of the span. Distributed load is reduced to the point load and is applied to the connection between deck and suspensions. There are 39 possible points of load application (Fig. 8).

Position of each web element of cable truss is defined by the distance from the pylon to the connection of web element with the top chord, depending on the distance from the pylon to the connection of the same element with the bottom chord (Fig. 11). The web elements are divided into two groups - elements inclined to the centre of cable truss and elements inclined to the edges of cable truss. Each element of the web can have its own angle on inclination. The second order polynomial equation is assumed to express position of each web element and to minimize amount of variable factors.

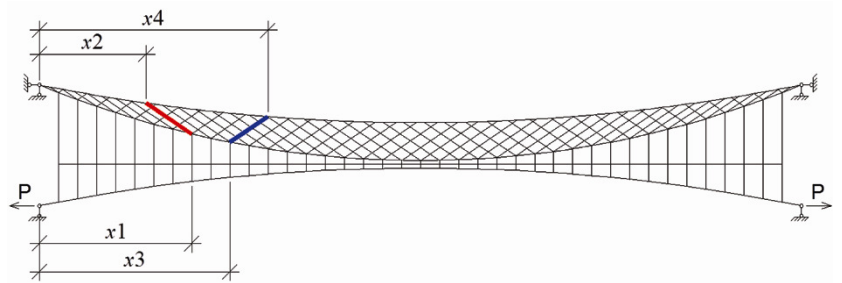

Fig. 11. Position of web elements

The position of web elements, which are inclined to the edges of cable truss are expressed by Eq. (1), the position of web elements, inclined to the edges of cable truss, can be expressed by Eq. (2):

$$
\begin{aligned}
& x_{2}=x_{1}-\left(\operatorname{root} 1 \cdot x_{1}^{2}+\operatorname{root} 2 \cdot x_{1}+\operatorname{root} 3\right), \\
& x_{4}=x_{3}+\left(\operatorname{root} 4 \cdot x_{3}^{2}+\operatorname{root} 5 \cdot x_{3}+\operatorname{root} 6\right),
\end{aligned}
$$

where: $x_{2}$ and $x_{4}$ - distances from the pylon to the connection of web element and top cord; $x_{1}$ and $x_{3}$ - distances from the pylon to the connection of web element and bottom cord; root 1 ...root 6 - roots of the system of Eqs. (3).
The roots of the polynomial equation for web elements inclined to the edges of cable truss were found solving system of Eqs. (3):

$$
\left\{\begin{array}{l}
s_{1}=\operatorname{root} 1 \cdot a 1^{2}+\operatorname{root} 2 \cdot a 1+\operatorname{root} 3, \\
s_{2}=\operatorname{root} 1 \cdot a 2^{2}+\operatorname{root} 2 \cdot a 2+\operatorname{root} 3, \\
s_{3}=\operatorname{root} 1 \cdot a 3^{2}+\operatorname{root} 2 \cdot a 3+\operatorname{root} 3,
\end{array}\right.
$$

where: $s_{1}$ - distance $x_{2}$ for $x_{1}=a_{1} ; s_{2}-$ distance $x_{2}$ for $x_{1}=$ $a_{2} ; s_{3}$ - distance $x_{2}$ for $x_{1}=a_{3} ; a_{1}$ - distance from the pylon to the connection of first web element with bottom chord; $a_{2}$ - distance from the pylon to the connection of middle web element with bottom chord; $a_{3}$ - distance from the pylon to the connection of last web element with bottom chord, counting for the middle of span.

Roots $4-6$ can be found by the same way for distances $s_{4}, s_{5}$ and $s_{6}$, respectively.

Distribution of material among cable truss elements can be expressed by Eq. (4):

$$
\begin{aligned}
& g=g_{b}+g_{t}+g_{w}, \\
& g_{1}=g_{b} / g, \\
& g_{3}=g_{w} / g,
\end{aligned}
$$

where: $g$ - material consumption of cable truss; $g_{b}$ - material consumption of bottom chord; $g_{t}$ - material consumption of top chord; $g_{w}$ - material consumption of web elements.

\section{Optimization of cable truss for prestressed suspension bridge}

\subsection{Definition of optimization problem}

The aim of optimization is to evaluate rational from the point of view of total vertical displacements minimization characteristics of cable truss for prestressed suspension bridge.

Rational structure of cable truss is defined by rational camber of top chord $\left(f_{t}\right)$, rational position of web elements (defined by distances $s_{1}, s_{2}, s_{3}, s_{4}, s_{5}, s_{6}$ ) and rational distribution of material among cable truss elements (defined by rations $g_{1}$ and $g_{2}$ ).

Bottom chord camber $f_{b}$, material consumption of cable truss $g$, material consumption of stabilization cable; level of prestressing, bridge geometrical parameters: pylon height, main span and suspension step are considered as constants of optimization.

Distances $s_{1}, s_{2}, s_{3}, s_{4}, s_{5}, s_{6}$, rations $g_{1}$ and $g_{2}$ and relation of top and bottom chord cambers $f_{t} / f_{b}$ are variable factors for optimization.

Optimization problem is to minimize objective function:

$$
w_{t o t}\left(s_{1}, s_{2}, s_{3}, s_{4}, s_{5}, s_{6}, g_{1}, g_{2}, \frac{f_{t}}{f_{b}}\right),
$$

subject to:

$$
[K(U)] \cdot\{U\}=[F(U)],
$$

and Eqs. (2)-(4), where $[K(U)]$ is stiffness matrix, $\{U\}$ is displacement vector and $[F(U)]$ is force vector. 
Total displacements $w_{t o t}$ are found by summing displacements upwards $w^{+}$and displacements downwards $\mathrm{w}^{-}$ (Fig. 12). Maximum vertical displacements for suspended cable structures appears under the action of load applied to different parts of span, therefore different loading cases were analysed. The problem has to be solved in static and in non-linear stage.

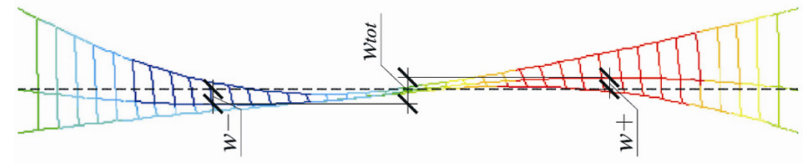

Fig. 12. Deformed shape of prestressed suspension bridge in non-symmetrical loading case

\subsection{Calculation of rational characteristics of cable truss for suspension bridge}

The cable truss optimization with 9 variable factors is done by genetic algorithm (Lute et al. 2009; Šešok et al. 2010; Montgomery 2001; Fletcher 2000).

The genetic algorithm is a method for solving both constrained and unconstrained optimization problems that are based on natural selection, the process that drives biological evolution. The genetic algorithm repeatedly modifies a population of individual solutions. At each step, the genetic algorithm selects individuals at random from the current population to be parents and uses them to produce the children for the next generation. Over successive generations, the population "evolves" towards an optimal solution (Fig. 13). Genetic algorithms are used to solve a variety of optimization problems that are not well suited for standard optimization algorithms, including problems in which the objective function is discontinuous, non-differentiable, stochastic, or highly nonlinear (MathWorks 2011).

The genetic algorithm uses three main types of rules at each step to create the next generation from the current population:

- Selection rules select the individuals, called parents, which contribute to the population at the next generation;

- Crossover rules combine two parents to form children for the next generation;

- Mutation rules apply random changes to individual parents to form children (MathWorks 2011).

GA Toolbox of mathematical software MatLAB was used in the optimization. Special program was written in MatLAB programming environment to calculate fitness using FEM (Šliseris, Rocēns 2011). FEM program ANSYS was used to calculate displacements of suspension bridge (Basov 2005). Specially written MatLAB function calls ANSYS and ANSYS returns vertical displacements. The ANSYS models of suspension bridges with single cable and cable truss are shown in Figs 14 and 15 .

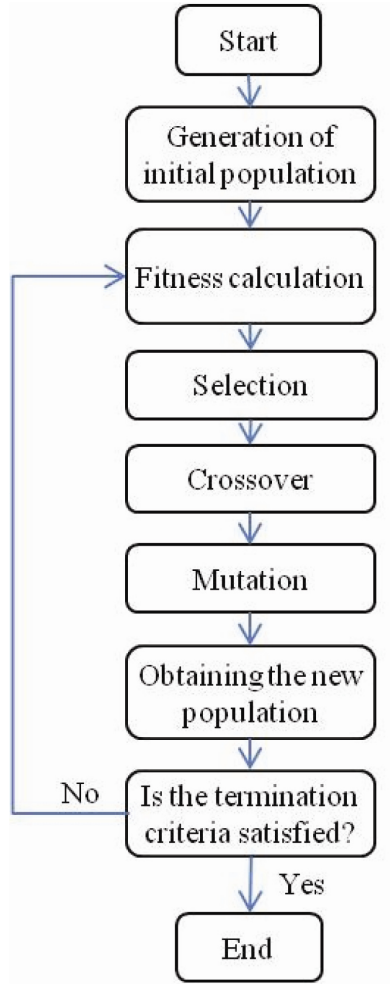

Fig. 13. Flowchart of genetic algorithm

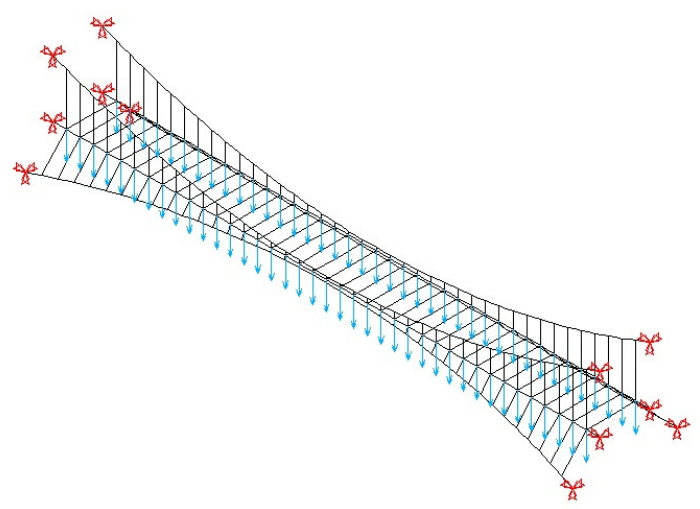

Fig. 14. ANSYS model of prestressed suspension bridge with single cable

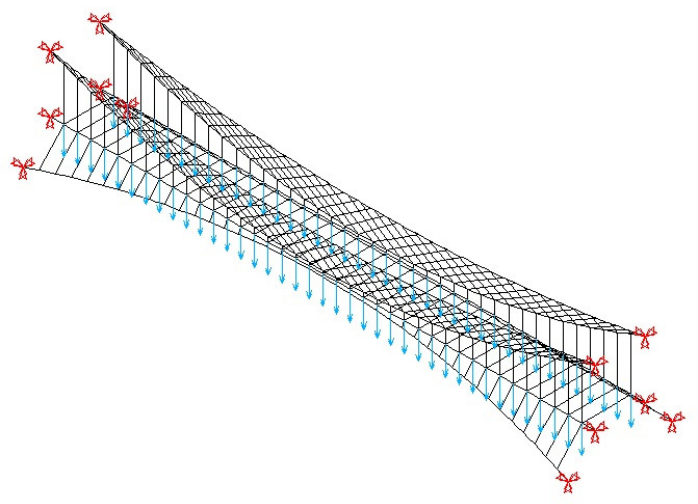

Fig. 15. ANSYS model of prestressed suspension bridge with cable truss 
Cable truss is modelled by two node link type compression less finite elements (LINK10 in ANSYS). The analysis type is geometrically nonlinear static including large-deflection effects, because suspension cable structures are characterized with large deflections before stabilization (Šliseris, Rocēns 2010; Eurocode 3 2007).

Rational characteristics of cable truss were evaluated. Rational relation of top chord camber and bottom chord camber: $f_{t} / f_{b}=0.4764$. Rational relation of material consumption of bottom chord and material consumption of whole truss: $g_{b} / g=0.4480$. Rational relation of web elements material consumption and material consumption of whole truss: $g_{w} / g=0.0699$. Rational values of distances $s_{1}, s_{2}, s_{3}, s_{4}, s_{5}$ and $s_{6}$ are $4.8333 \mathrm{~m}, 16.4532 \mathrm{~m}$, $15.8669 \mathrm{~m}, 1.1640 \mathrm{~m}, 11.7204 \mathrm{~m}$ and $15.4622 \mathrm{~m}$, respectively.

Rational position of web elements inclined to the edges of cable truss can be found from distances $s_{1}, s_{2}$ and $s_{3}$. It is expressed by rational value of distance $x_{2}$ of each web element on distance $x_{1}$ from the pylon in the form of polynomial Eq. (7):

$$
x_{2}=2.8415 \cdot 10^{-3} \cdot x_{1}^{2}+0.5854 \cdot x_{1}-2.8318,
$$

where: $x_{1}$ - distance from the pylon to the bottom chord's node; $x_{2}$ - distance from the pylon to the top chord's node.

Rational position of web elements inclined to the edges of cable truss can be found from distances $s_{4}, s_{5}$ and $s_{6}$. It is expressed by rational value of distance $x_{4}$ of each web element on distance $x_{3}$ from the pylon in the form of polynomial Eq. (8):

$$
x_{4}=-1.6815 \cdot 10^{-3} \cdot x_{3}^{2}+1.3271 \cdot x_{3}-0.4292,
$$

where: $x_{3}$ - distance from the pylon to the bottom chord's node; $x_{4}$ - distance from the pylon to the top chord's node.

\section{Comparative analysis of bridges with single cable and cable truss}

Displacements of prestressed suspension bridges with rational cable truss and single cable were compared. The material consumption of cable truss is the same as material consumption of single cable. The analysis were carried out by the FEM software ANSYS.

Maximum displacements of prestressed suspension bridge with single cable are achieved if load is applied to points from 1 to 21 (see Fig. 8). Maximum displacements of prestressed suspension bridge with cable truss are achieved if load is applied to points from 1 to 23 (see Fig. 8). Dependence of maximum displacement and number of points with applied load for prestressed suspension bridges with single cable and cable truss are shown in Figs 16 and 17, respectively.

Maximum displacements of prestressed suspension bridge with single cable, where load is applied to points from 1 to 21, are situated in second quarter (Fig. 18). Maximum displacements of prestressed suspension bridge with cable truss, where load is applied to points from 1 to 21 , are closer to centre part (Fig. 19). For suspension bridge with single cable maximum displacements upwards and downwards appear if load is applied to points form 1 to 21 , but for the structure with cable truss maximum displacements upwards appear if load is applied to points from 1 to 17, but maximum displacements downwards appear, if load is applied to points from 1 to 34 .

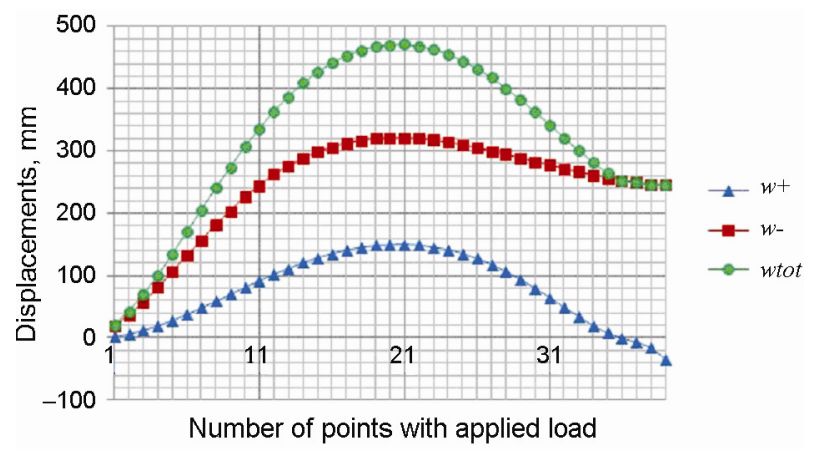

Fig. 16. Dependence of maximum displacement and number of points with applied load for suspension bridge with single cable

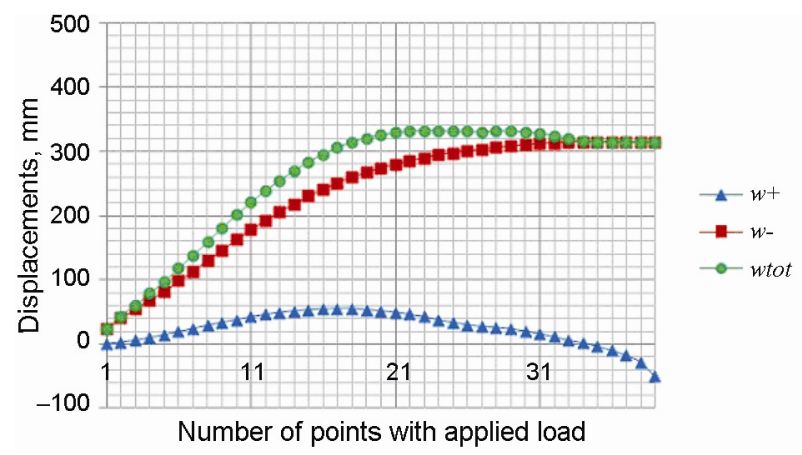

Fig. 17. Dependence of maximum displacement and number of points with applied load for suspension bridge with cable truss

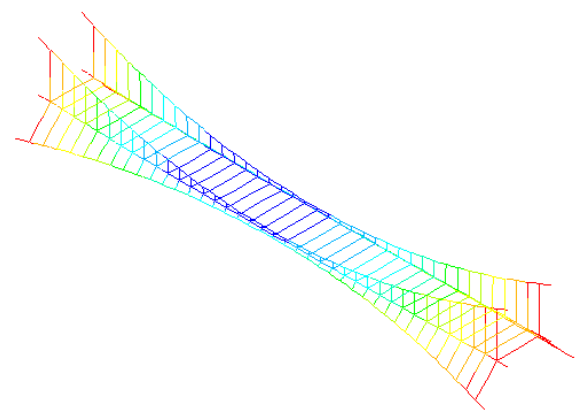

Fig. 18. Deformation scheme of prestressed suspension bridge with single cable

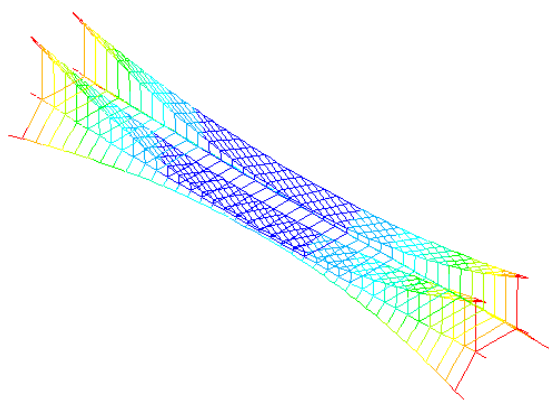

Fig. 19. Deformation scheme of prestressed suspension bridge with cable truss 
Maximum vertical displacements in the case of the worst situated load are shown in Table 1. The difference between maximum displacements upwards of prestressed suspension bridges with single cable and cable truss is $63.1 \%$. The difference between maximum displacements downwards is $1.8 \%$. The maximum total displacements are reduced up to $29.4 \%$ by using cable truss instead of single cable in the case of the worst situated load.

Table 1. Displacements of prestressed suspension bridge with cable truss and single cable

\begin{tabular}{c|c|c|c|c}
\hline $\begin{array}{c}\text { Prestressed } \\
\text { suspension } \\
\text { bridge struc- } \\
\text { ture }\end{array}$ & $\begin{array}{c}\text { Load } \\
\text { applica- } \\
\text { tion } \\
\text { points }\end{array}$ & $\begin{array}{c}\text { Maximum } \\
\text { deck dis- } \\
\text { placements } \\
\text { downwards, } \\
\text { mm }\end{array}$ & $\begin{array}{c}\text { Maximum } \\
\text { deck dis- } \\
\text { placements } \\
\text { upwards, } \\
\text { mm }\end{array}$ & $\begin{array}{c}\text { Maximum } \\
\text { deck total } \\
\text { displace- } \\
\text { ments, mm }\end{array}$ \\
\hline Single cable & $1-21$ & $\mathbf{3 2 0 . 9}$ & $\mathbf{1 5 0 . 5}$ & $\mathbf{4 7 1 . 4}$ \\
\hline \multirow{2}{*}{ Cable truss } & $1-17$ & 251.0 & $\mathbf{5 5 . 5}$ & 306.5 \\
\cline { 2 - 5 } & $1-34$ & $\mathbf{3 1 4 . 9}$ & 1.9 & 316.8 \\
\cline { 2 - 5 } & $1-23$ & 290.2 & 42.5 & $\mathbf{3 3 2 . 7}$ \\
\hline
\end{tabular}

\section{Physical models testing}

Two small scale physical models of prestressed suspension bridge were constructed to confirm advantages of the cable truss in comparison with the single cable from the point of view of vertical displacements minimization (Figs 20 and 21). The rational relations of top and bottom chords, rational distribution of materials consumption among cable truss elements and rational position of web elements achieved by the optimization, described in Section 3, were used for creation of the physical models of prestressed suspension bridge with cable truss.

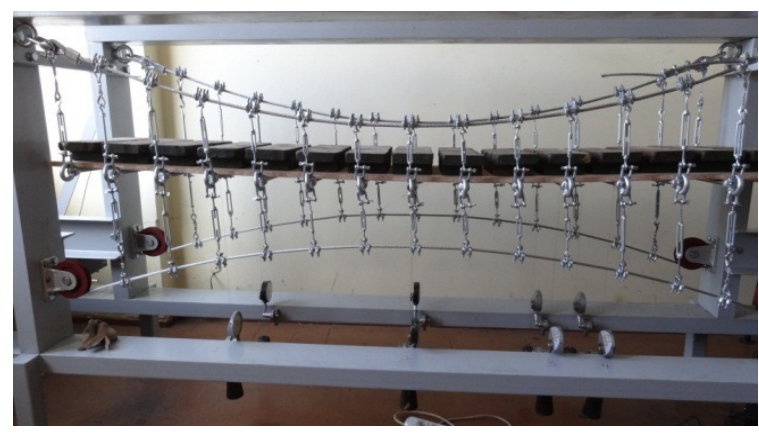

Fig. 20. Physical model of prestressed suspension bridge with single cable

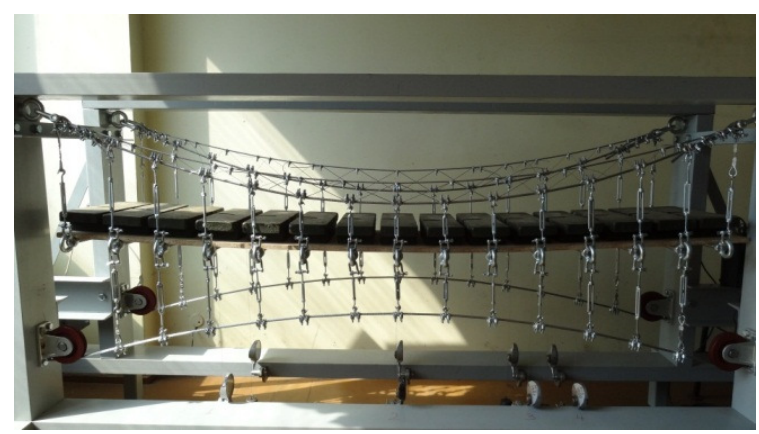

Fig. 21. Physical model of prestressed suspension bridge with cable truss

\subsection{Description of the physical models}

The span of the physical models of prestressed suspension bridge is equal to $2.1 \mathrm{~m}$. Top chord camber is equal to 22 centimetres. The deck is connected to main load carrying structure by suspensions in 15 points (Fig. 22).
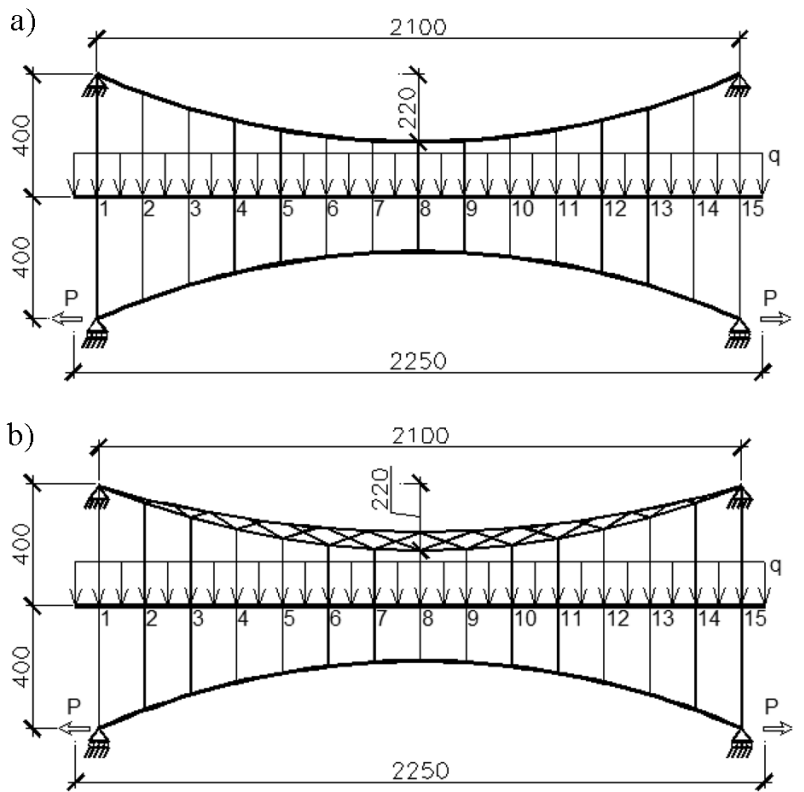

Fig. 22. Scheme of the suspension bridge physical models: (a) scheme of the model with single cable; (b) - scheme of the model with cable truss

The elements of the prestressed suspension bridges models are made of steel cables with modulus of elasticity $60000 \mathrm{MPa}$. The diameters of elements are shown in Table 2 . The diameters of elements are specially selected to produce the same material consumption single cable and cable truss experimental models.

Table 2. Characteristics of cable elements of the physical models

\begin{tabular}{l|c|c|c}
\hline \multicolumn{1}{c|}{ Elements } & Cable type & Diameter & $\begin{array}{c}\text { Breaking } \\
\text { force }\end{array}$ \\
\hline \multicolumn{3}{c}{ Physical model with single cable } \\
\hline Main cable & $6 \times 19+$ WSC & $10.0 \mathrm{~mm}$ & $63.0 \mathrm{kN}$ \\
\hline $\begin{array}{l}\text { Stabilization } \\
\text { cable }\end{array}$ & $6 \times 19+$ WSC & $8.0 \mathrm{~mm}$ & $40.3 \mathrm{kN}$ \\
\hline \multicolumn{4}{c}{ Physical model with cable truss } \\
\hline Bottom chord & $6 \times 19+$ WSC & $8.0 \mathrm{~mm}$ & $40.3 \mathrm{kN}$ \\
\hline Top chord & $6 \times 19+$ WSC & $5.5 \mathrm{~mm}$ & $17.8 \mathrm{kN}$ \\
\hline Web elements & $6 \times 7+$ WSC & $2.0 \mathrm{~mm}$ & $2.7 \mathrm{kN}$ \\
\hline $\begin{array}{l}\text { Stabilization } \\
\text { cable }\end{array}$ & $6 \times 19+$ WSC & $8.0 \mathrm{~mm}$ & $40.3 \mathrm{kN}$ \\
\hline
\end{tabular}

The deck of the models of prestressed suspension bridges is made from oriented strand board (OSB). It does not have significant load bearing capacity. It only distributes load among suspensions due to deformability of OSB. 


\subsection{Process of physical models testing}

Initial extension should be done for cable structures to minimize non-elastic deformations, which are caused by cable structure. The physical models were initially extensioned by the load, which is by $20 \%$ larger than design load.

The prestressing is organized in stabilization cable. The models were prestressed by load $1000 \mathrm{~kg}$ for each side. Two types of loading were applied to model: symmetrical and non-symmetrical. The load was applied to the deck by placing weights approximately $20 \mathrm{~kg}$ each. The experimental models were loaded up to load $2755 \mathrm{~kg}$ with step $285 \mathrm{~kg}$ in symmetrical loading case (Fig. 23). The models were loaded up to load $1495 \mathrm{~kg}$ with step $155 \mathrm{~kg}$ in non-symmetrical loading case (Fig. 24).

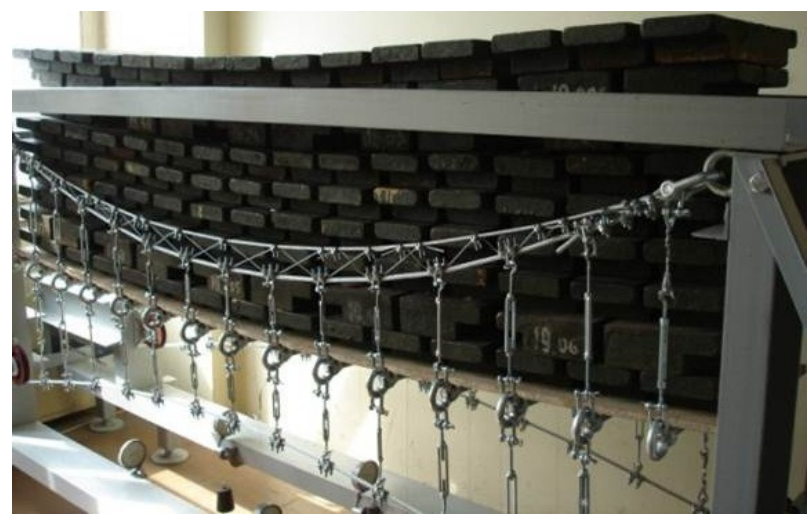

Fig. 23. Symmetrical load applied to the physical model of prestressed suspension bridge with cable truss

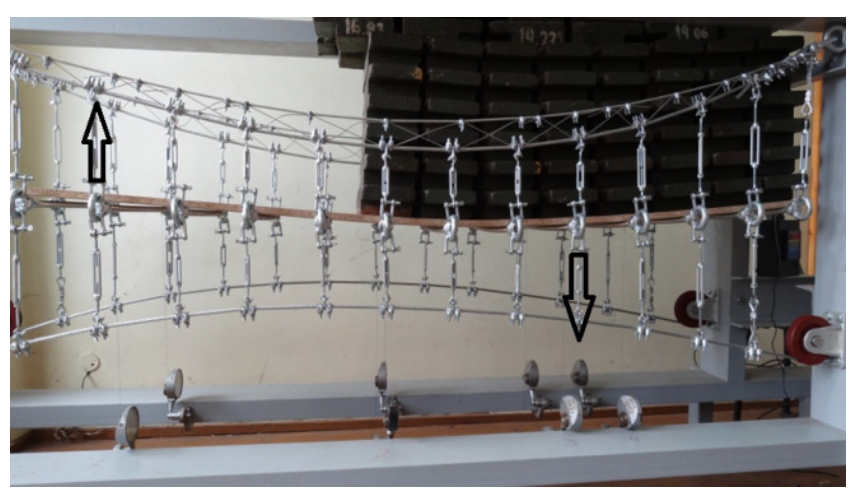

Fig. 24. Non-symmetrical load applied to the physical model of prestressed suspension bridge with cable truss

\subsection{Results of model testing}

The models were tested by symmetrical and nonsymmetrical loads. Loaded part moves downwards, but unloaded part moves upwards in the case of nonsymmetrical loading (Fig. 24).

The displacements of physical models of prestressed suspension bridges with single cable and cable truss in the case of symmetrical loading are shown in Fig. 25. The displacements of the models in the case of nonsymmetrical loading are shown in Fig. 26. It was shown that displacements in the case of non-symmetrical loading are larger than in the case of symmetrical loading. The

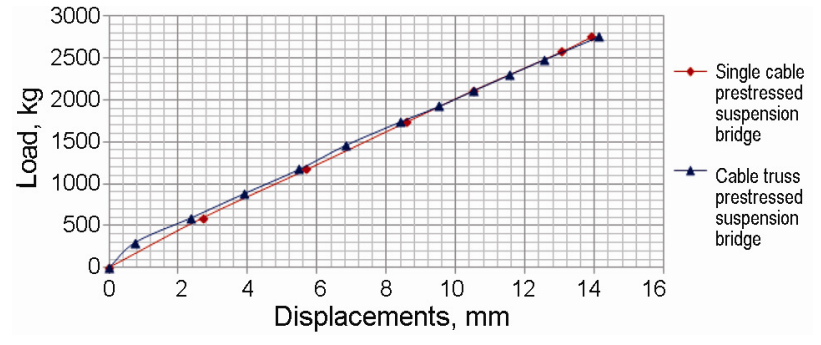

Fig. 25. Results of model testing in symmetrical loading case

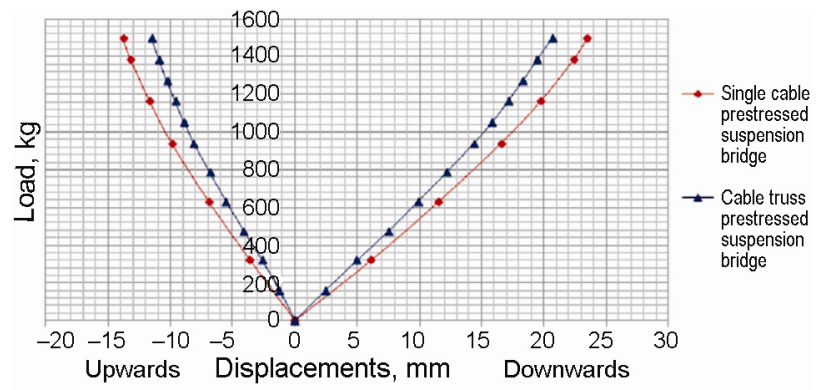

Fig. 26. Results of model testing in non-symmetrical loading case

displacements from symmetrical load are almost the same for physical models with single cable and cable truss, but displacements from non-symmetrical load are smaller for physical model of prestressed suspension bridge with cable truss.

The displacements were calculated numerically by FEM software ANSYS and were compared with experimental results. Scheme of deformation of prestressed suspension bridge with cable truss is shown in the Fig. 27.

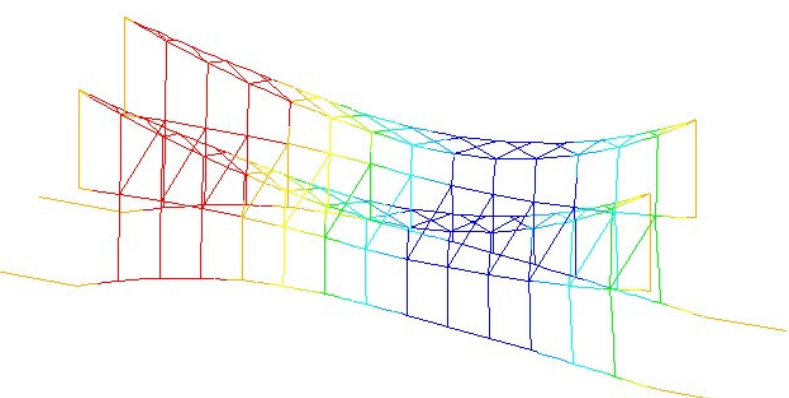

Fig. 27. Scheme of cable truss displacements

The maximum vertical displacements are generalized in Table 3. The difference between experimental and simulated (FEM) displacements of models of prestressed suspension bridge with single cable and cable truss is shown in Table 4.

The displacements of physical models of prestressed suspension bridges with single cable and cable truss in the case of symmetrical loading are equal to $15 \mathrm{~mm}$, but in the case of unsymmetrical loading total displacements are 37 and $32 \mathrm{~mm}$, respectively. The experimental results are close to calculated ones. The difference between experimental and numerical results can be explained by nonsufficient deviation between geometrical parameters 
of physical and numerical models. The support joint displacements do not exceed 3\% of maximal structure displacements. The experimental results show, that replacing single cable with cable truss with the cross web decreases vertical displacements upwards by $16 \%$ and downwards by $12 \%$. The total displacements decrease by $13 \%$ at the same time.

Table 3. Experimental and FE simulated (in brackets) displacements of the physical models

\begin{tabular}{|c|c|c|c|}
\hline $\begin{array}{l}\text { Loading } \\
\text { scheme }\end{array}$ & $\begin{array}{l}\text { Deck maxi- } \\
\text { mum dis- } \\
\text { placements } \\
\text { downwards, } \\
\text { mm }\end{array}$ & $\begin{array}{l}\text { Deck maxi- } \\
\text { mum dis- } \\
\text { placements } \\
\text { upwards, mm }\end{array}$ & $\begin{array}{l}\text { Deck maxi- } \\
\text { mum total } \\
\text { displace- } \\
\text { ments, mm }\end{array}$ \\
\hline \multicolumn{4}{|c|}{$\begin{array}{l}\text { Physical model of prestressed suspension bridge } \\
\text { with single cable }\end{array}$} \\
\hline $\begin{array}{l}\text { Symmet- } \\
\text { rical load }\end{array}$ & $14.71(13.92)$ & & \\
\hline $\begin{array}{l}\text { Non- } \\
\text { symmetrical } \\
\text { load }\end{array}$ & $23.81(21.79)$ & $13.83(14.25)$ & $37.64(36.04)$ \\
\hline \multicolumn{4}{|c|}{$\begin{array}{c}\text { Physical model of prestressed suspension bridge } \\
\text { with cable truss }\end{array}$} \\
\hline $\begin{array}{l}\text { Symmet- } \\
\text { rical load }\end{array}$ & $15.06(14.76)$ & & \\
\hline $\begin{array}{l}\text { Non- } \\
\text { symmetrical } \\
\text { load }\end{array}$ & $21.04(21.06)$ & $11.61(10.38)$ & 32.65 (31.44) \\
\hline
\end{tabular}

Table 4. Difference between displacements of physical models with single cable and cable truss

\begin{tabular}{l|c|c}
\hline & $\begin{array}{c}\text { Experimental } \\
\text { results }\end{array}$ & $\begin{array}{c}\text { Numerical } \\
\text { results }\end{array}$ \\
\hline \multicolumn{3}{c}{ Symmetrical load } \\
\hline $\begin{array}{l}\text { Deck displacements } \\
\text { downwards }\end{array}$ & $-2.4 \%$ & $-6.0 \%$ \\
\hline \multicolumn{3}{c}{ Non-symmetrical load } \\
\hline $\begin{array}{l}\text { Deck displacements } \\
\text { upwards }\end{array}$ & $16.1 \%$ & $27.2 \%$ \\
\hline $\begin{array}{l}\text { Deck displacements } \\
\text { downwards }\end{array}$ & $11.6 \%$ & $3.4 \%$ \\
\hline Deck displacements total & $13.3 \%$ & $12.8 \%$ \\
\hline
\end{tabular}

\section{Conclusions}

Rational structure of the cable truss for prestressed suspension bridge with span equal to $200 \mathrm{~m}$ was developed. The vertical displacement was considered as criteria of rationality of cable truss structure. Rational relation of top chord camber and bottom chord camber is equal to 0.48 , rational relation of bottom chord material consumption and material consumption of whole truss is equal to 0.45 and rational relation of web elements material consumption and material consumption of whole truss is equal to 0.07 .

It was stated, that usage of cable truss with the developed cross web as a main load-carrying structure of prestressed suspension bridge instead of single cable reduce the vertical displacements upwards by $63.1 \%$, downwards by $1.8 \%$ and total displacements by $29.4 \%$ in the case of the worst situated vertical load.
The results obtained during optimization were verified on the small scale physical models of prestressed suspension bridges. The physical models with single cable and cable truss were tested and analysed. Experimental results are close to numerical ones. The obtained results indicate, that usage of cable truss with the cross web as main load-carrying structure of prestressed suspension bridge instead of single cable allows for the reduction of vertical displacements upwards by $16 \%$, downwards by $12 \%$ and total displacements by $13 \%$ in the case of non-symmetrical load.

\section{Acknowledgments}

This work has been supported by the European Social Fund within the project "Support for the implementation of doctoral studies at Riga Technical University".

\section{References}

Achkire, Y.; Preumont, A. 1996. Active tendon control of cablestayed bridges, Earthquake Engineering \& Structural Dynamics 25(6): 585-597. http://dx.doi.org/10.1002/(SICI)1096-9845(199606)25: $6<585:: A I D-E Q E 570>3.0 . C O ; 2-I$

Bakhtin, S.; Ovchinnikov, I.; Inamov, R. 1999. Visiachie $i$ vantovye mosty. Saratov: Sarat. gos. tekhn. un-t. $124 \mathrm{~s}$.

Basov, K. 2005. ANSYS: spravochnik polzovatelia. Moskva: DMk Press. $640 \mathrm{~s}$.

Chen, W. F.; Lui, E. M. 2005. Handbook of structural engineering. New York: CRC Press. 625 p. http://dx.doi.org/10.1201/9781420039931

Chen, W. F.; Duan, L. 2000. Bridge Engineering Handbook. New York: CRC Press LLC. 452 p.

Eurocode 1: Actions on structures. Part 2: Traffic loads on bridges. Brussels, 2004. 162 p.

Eurocode 3: Design of steel structures. Part 1-11: Design of structures with tensile components. Brussels, 2007. 35 p.

Feyrer, K. 2007. Wire Ropes. Berlin: Springer-Verlag Berlin Heidelberg. 317 p. http://dx.doi.org/10.1007/978-3-540-33831-4

Fiberline Composites A/S. 2002. Design Manual. Middelfart: Fiberline Composites A/S. 326 p. http://dx.doi.org/10.1071/MR02001

Fletcher, R. 2000. Practical methods of optimization. 2nd ed. London: John Willey \& Sons Inc. 451 p.

Goremikins, V.; Serdjuks, D. 2010a. Rational structure of trussed beam, in Proc. of the 10th International Conference "Modern Building Materials, Structures and Techniques”, 19-21 May, 2010, Vilnius, Lithuania, 613-618.

Goremikins, V.; Rocens, K.; Serdjuks, D. 2010b. Rational structure of composite trussed beam, in Proc. of the 16th International Conference "Mechanics of Composite Materials", 16-20 May, 2010, Riga, Latvia, 75.

Goremikins, V.; Rocens, K.; Serdjuks, D. 2010c. Evaluation of Rational Parameters of Trussed Beam, Scientific Journal of RTU. 2. series., Construction Science 11: 21-25.

Goremikins, V.; Rocens, K.; Serdjuks, D. 2010d. Rational large span structure of composite pultrusion trussed beam, Scientific Journal of RTU. 2. series., Construction Science 11: $26-31$.

Goremikins, V.; Rocens, K.; Serdjuks, D. 2011. Rational structure of cable truss, World Academy of Science, Engineer- 
ing and Technology. Special Journal Issues 0076: 571578.

Grigorjeva, T.; Juozapaitis, A.; Kamaitis, Z.; Paeglitis, A. 2008. Finite element modelling for static behaviour analysis of suspension bridges with varying rigidity of main cables, The Baltic Journal of Road and Bridge Engineering 3(3): 121-128. http://dx.doi.org/10.3846/1822-427X.2008.3.121-128

Grigorjeva, T.; Juozapaitis, A.; Kamaitis, Z. 2010. Static analyses and simplified design of suspension bridges having various rigidity of cables, Journal of Civil Engineering and Management 16(3): 363-371. http://dx.doi.org/10.3846/jcem.2010.41

Hambly, E. C. 1998. Bridge Deck Behaviour. 2nd ed. New York: E \& FN Spon. 308 p.

Juozapaitis, A.; Idnurm, S.; Kaklauskas, G.; Idnurm, J.; Gribniak, V. 2010. Non-linear analysis of suspension bridges with flexible and rigid cables, Journal of Civil Engineering and Management 16(1): 149-154. http://dx.doi.org/10.3846/jcem.2010.14

Kirsanov, M. 1973. Visiachie sistemy povyshennoj zhestkosti. Moskva: Strojizdat. $116 \mathrm{~s}$.

Lute, V.; Upadhyay, A.; Singh, K. K. 2009. Computationally efficient analysis of cable-stayed bridge for GA-based optimization, Engineering Applications of Artificial Intelligence 22(4-5): 750-758. http://dx.doi.org/10.1016/j.engappai.2009.04.001

MathWorks. 2011. MATLAB User's manual. What Is the genetic algorithm. MathWorks.

Mikhailov, V. 2002. Predvaritelno napriazhennye kombinirovannye $i$ vantovye konstruktsii. Moskva: ASB. $256 \mathrm{~s}$.
Montgomery, D. C. 2001. Design and analysis of experiments. 5th ed. New York: John Willey \& Sons Inc. 697 p.

Serdjuks, D.; Rocens, K. 2004. Decrease the displacements of a composite saddle-shaped cable roof, Mechanics of Composite Materials 40(5): 675-684. http://dx.doi.org/10.1023/B:MOCM.0000047234.72813.2e

Strasky, J. 2005. Stress Ribbon and Cable Supported Pedestrian Bridge. London: Thomas Telford Publishing. 213 p. http://dx.doi.org/10.1680/sracspb.32828

Šešok, D.; Mockus, J.; Belevičius, R.; Kačeniauskas, A. 2010. Global optimization of grillages using Simulated annealing and high performance computing, Journal of Civil Engineering and Management 16(1): 95-101. http://dx.doi.org/10.3846/jcem.2010.09

Šliseris, J.; Rocēns, K. 2010. Curvature analysis for composite with orthogonal, asymmetrical multi-layer structure, Journal of Civil Engineering and Management 16(2): 242-248. http://dx.doi.org/10.3846/jcem.2010.28

Šliseris, J.; Rocēns, K. 2011. Rational structure of panel with curved plywood ribs, in ICBSE 2011: "International Conference on Building Science and Engineering”, 27-29 April, 2011, Venice, Italy, 76: 317-323.

Tibert, G. 1999. Numerical Analyses of Cable Roof Structures. Stockholm: KTH, TS-Hogskoletryckeriet. 196 p.

Walther, R.; Houriet, B.; Isler, W.; Moia, P.; Klein, J. F. 1999. Cable Stayed Bridges. 2nd ed. London: Thomas Telford. 236 p. http://dx.doi.org/10.1680/csb.27732

Xiang, R.; Ping-ming, H.; Kui-hua, M.; Zhi-hua, P. 2009. Influence of temperature on main cable sagging of suspension bridge, Journal of Zhengzhou University Engineering Science 30(4): 22-25.

Vadims GOREMIKINS. PhD student. Researcher at Building Science Centre of Riga Technical University, Latvia. Assistant at the Dept. of Structural Engineering of Riga Technical University, Latvia. Author and co-author of 12 scientific and methodological publications. Research interests: cable structures, suspension bridges.

Karlis ROCENS. Dr Habil Sc. Ing., Prof. at Dept. of Structural Engineering and director at Institute of Structural Engineering and Reconstruction of Riga Technical University, Latvia. Full member of Latvian academy of sciences. Author of 5 monographs and more than 250 scientific articles. Research interests: modern structures, technological mechanics of wood and composite materials and structural material science.

Dmitrijs SERDJUKS. Dr Sc. Ing., Prof. at Dept. of Structural Engineering of Riga Technical University, Latvia. Author and co-author of more than 50 scientific and methodological publications. Research interests: steel and composite structures. 